\title{
ON-LINE PRECONCENTRATION SYSTEM USING A MICROCOLUMN PACKED WITH ALIZARIN RED S-MODIFIED ALUMINA FOR ZINC DETERMINATION BY FLAME ATOMIC ABSORPTION SPECTROMETRY
}

\author{
A.M. Haji Shabani, S. Dadfarnia and T. Moosavinejad \\ Department of Chemistry, Faculty of Science, Yazd University, Yazd, Iran \\ Seyyed Hamid Ahmadi* \\ Chemistry and Chemical Engineering Research Center of Iran, Tehran, Iran
}

Recebido em 10/6/08; aceito em 15/12/08; publicado na web em 28/5/09

\begin{abstract}
A simple and sensitive on-line flow injection system for determination of zinc with FAAS has been described. The method is based on the separation and preconcentration of zinc on a microcolumn of immobilized Alizarin Red S on alumina. The adsorbed analyte is then eluted with $250 \mu \mathrm{L}$ of nitric acid $\left(1 \mathrm{~mol} \mathrm{~L}^{-1}\right)$ and is transported to flame atomic absorption spectrometer for quantification. The effect of $\mathrm{pH}$, sample and eluent flow rates and presence of various cations and anions on the retention of zinc was investigated. The sorption of zinc was quantitative in the $\mathrm{pH}$ range of 5.5-8.5. For a sample volume of $25 \mathrm{~mL}$ an enrichment factor of 144 and a detection limit (3S) of $0.2 \mu \mathrm{g} \mathrm{L}-1$ was obtained. The precision (RSD, $\mathrm{n}=7$ ) was $3.0 \%$ at the $20 \mu \mathrm{g} \mathrm{L}{ }^{-1}$ level. The developed system was successfully applied to the determination of zinc in water samples, hair, urine and saliva.
\end{abstract}

Keywords: Alizarin Red S; on-line preconcentration; zinc determination.

\section{INTRODUCTION}

Zinc is among the most important trace elements in human nutrition. It is a cofactor for more than 300 enzymes. ${ }^{1}$ Zinc compounds have been employed in solutions as antiseptic and disinfectant agents. However, its excess can play an important role in the progression of some damages to human body, including disturbances of energy metabolism and increase in oxidative stress. ${ }^{2}$ Thus, determination of zinc in natural waters, biological and environmental samples is of great importance.

The atomic spectrometry techniques are extensively employed for the quantification of metal species. Among these techniques, flame atomic absorption spectrometry (FAAS) presents desirable characteristics, such as good selectivity, low cost, operational facilities and high analytical frequency. ${ }^{3}$ However, the direct determination of trace metals by this technique is usually difficult because of low concentration of metal ions in samples and interference of matrices. These problems can be overcome by using separation and or preconcentration procedures before the analysis. For the determination of zinc, various preconcentration methods, such as liquid-liquid extraction, ${ }^{4}$ solid phase extraction, ${ }^{5-7}$ cloud point extraction, ${ }^{8,9}$ precipitation ${ }^{10}$ and flotation ${ }^{11}$ have been proposed.

On-line separation and preconcentration using flow injection techniques have been shown to be efficient in enhancing the sensitivity and selectivity of flame atomic absorption spectrometry (FAAS). ${ }^{12,13}$ They exhibit some favorable features over their batch systems such as low sample and reagent consumption, less risk of contamination, enrichment efficiencies and reproducibility, simple automated operation and high sample throughput. ${ }^{3}$ Microcolumns containing chelating sorbent, ${ }^{14,15}$ activated carbon, ${ }^{16,17} \mathrm{C}_{18}$ octadecyl bonded silica ge ${ }^{18}$ and various other materials have been used for FI on-line separation and preconcentration of trace metals before determination with AAS.

Activated alumina is one of the most commonly used sorbent for preconcentration and separation of trace elements in flow injection atomic spectrometry. ${ }^{19,20}$ Depending on the solution $\mathrm{pH}$, activated alumina can function as either a cation or anion exchanger. Activated alumina displays a high affinity for a wide range of cations in basic conditions $^{21,22}$ while, it exhibits a high affinity for anionic species in

\footnotetext{
*e-mail: ahmadi@ccerci.ac.ir
}

acidic conditions ${ }^{23,24}$. Alumina modified with sulphoderavatives of aromatic ligands ${ }^{25,26}$ or sodium dodecyl sulfate/hydrophobic chelating agents ${ }^{27,28}$ have been used for the separation and preconcentration of trace elements in solid phase extraction.

Alizarin Red S (Figure 1) is a well known chelating agent and its use as a photometric reagent for determination of some cations has been fairly established. ${ }^{29}$ Alizarin Red S has also been used for solid phase extraction of traces of metal after its immobilization onto various supports, including anionic exchanger such as Sephadex QAE $\mathrm{A}-25^{30}$ and Dowex $1 \mathrm{X} 8-50^{31}$ and nonionic polymer sorbent such as Amberlite XAD- $7^{31}$ and XAD-2. ${ }^{32}$ In this work, Alizarin Red S was directly immobilized on alumina and an on-line system for the preconcentration and determination of zinc by FAAS was developed.<smiles>O=C1c2ccccc2C(=O)c2c1cc(S(=O)(=O)O)c(O)c2O</smiles>

Figure 1. Chemical structure of Alizarin Red S

\section{EXPERIMENTAL}

\section{Reagents}

All chemicals were of analytical reagent grade and were provided by Merck (Darmstadt, Germany). Doubly de-ionized water was used throughout for dilutions.

A stock standard solutions of (1000 $\left.\mathrm{mg} \mathrm{L}^{-1}\right)$ zinc(II) was prepared by dissolving $0.4549 \mathrm{~g}$ of $\mathrm{Zn}\left(\mathrm{NO}_{3}\right)_{2} \cdot 6 \mathrm{H}_{2} \mathrm{O}$ into a $100 \mathrm{~mL}$ volumetric flask and diluting to the mark with distilled water. This solution was standardized by complexometric titration with EDTA. Working solutions were prepared daily from the stock solutions by appropriate dilution with water.

Alumina ( $\gamma$-form $10-50 \mu \mathrm{m}$, chromatographic grade) was purified prior to use by shaking with $5 \mathrm{~mol} \mathrm{~L}^{-1}$ nitric acid and washing with water. 


\section{Preparation of the solid sorbent}

Purified alumina particles $(5 \mathrm{~g})$ were suspended in $50 \mathrm{~mL}$ of water and mixed with $0.3 \mathrm{~g}$ Alizarin Red $\mathrm{S}$. Then the suspension was acidified ( $\mathrm{pH} 2-2.5$ ) with $3 \mathrm{M}$ hydrochloric acid and was mixed for 20 min with a mechanical shaker. The produced solid phase (Alizarin Red S modified alumina) was then filtered with a sintered-glass funnel using the vacuum pump. The solid phase was washed with distilled water; air dried at room temperature and was kept in a closed bottle before use. The sorbent is stable at least for one month.

\section{Preparation of microcolumn}

The microcolumn used for preconcentration of analyte was prepared by packing $~ 80 \mathrm{mg}$ of Alizarin Red S-modified alumina in a PTFE (Teflon) tube with $1.5 \mathrm{~mm}$ i.d. and $3 \mathrm{~cm}$ length. A little glass wool was placed at the both ends to retain the sorbent in the tube.

\section{Apparatus}

A Buck Scientific Model 210 VGP flame atomic spectrometer, equipped with hollow cathode lamp and air-acetylene flame was used for zinc measurement. Zinc hollow cathode lamp was operated at $3.2 \mathrm{~mA}$ and the spectrometer was set to $213.9 \mathrm{~nm}$ with a slit width of $0.7 \mathrm{~nm}$. A Linseis $\mathrm{x}$-t chart model L-250 was used for monitoring the absorbance time response.

\section{Preparation of samples}

The human hair sample was rinsed with acetone, chloroform and doubly distilled water and then was dried at $60^{\circ} \mathrm{C}$. An exact weight of sample $(0.5 \mathrm{~g})$ was treated with $3 \mathrm{~mL}$ of concentrated $\mathrm{H}_{2} \mathrm{SO}_{4}$ and $\sim 30 \mathrm{~mL}$ concentrated $\mathrm{HNO}_{3}$ and was heated on a hot plate at 150 ${ }^{\circ} \mathrm{C}$ for 30 minutes. Finally, about $25 \mathrm{~mL}$ of $30 \% \mathrm{H}_{2} \mathrm{O}_{2}$ solution were gradually added until the solution turned colorless and was heated nearly to dryness at $200{ }^{\circ} \mathrm{C}$ to yield a whitish residue. Approximately $5 \mathrm{ml}$ of $0.1 \mathrm{~mol} \mathrm{~L}^{-1} \mathrm{HNO}_{3}$ was added to the baker and the contents were heated at $100{ }^{\circ} \mathrm{C}$ for $15 \mathrm{~min}$. The $\mathrm{pH}$ of solution was adjusted to $\sim 6.5$ and was diluted to $100 \mathrm{~mL}$ in a conical flask. $5 \mathrm{~mL}$ of this solution were then analyzed according to the given procedure.

Water, wastewater, saliva and urine samples were prepared as follows. ${ }^{33}$ Samples were filtered through a Millipore $0.45 \mu \mathrm{m}$ poresize membrane filter into cleaned polyethylene bottles, the $\mathrm{pH}$ of solutions were adjusted to $\sim 6.5$ and were treated according to the given procedure.

\section{Flow system operation}

The manifold of the flow system is shown schematically in Figure 2. Its operation can be divided into two steps: preconcentration and elution; in the first stage the sample at $\mathrm{pH} \sim 6.5$, was pumped at $5 \mathrm{~mL}$ min $^{-1}$ through the microcolumn containing Alizarin Red S modified alumina. Simultaneously the eluent loop $(250 \mu \mathrm{L})$ was filled with the eluent solution ( $1 \mathrm{~mol} \mathrm{~L}^{-1}$ nitric acid) and the baseline was set by pumping the carrier stream into the instrument nebulizer.

After the preconcentration stage both valves were manually switched and elution process was started. In this stage the content of the elution loop was displaced by the carrier stream to the microcolumn and so the analyte was desorbed from the sorbent owing to a high decrease in $\mathrm{pH}$, what reduced Alizarin Red S complexing capacity. Afterwards the sample plug was driven into the spectrometer where absorbance measurement was made. The transient signal was monitored and the peak height was used for quantitative analysis. a)

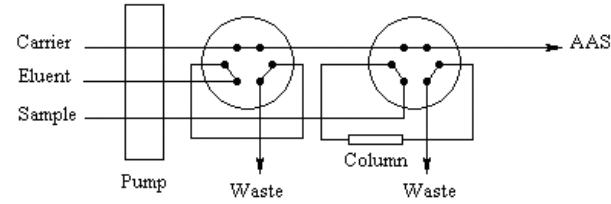

b)

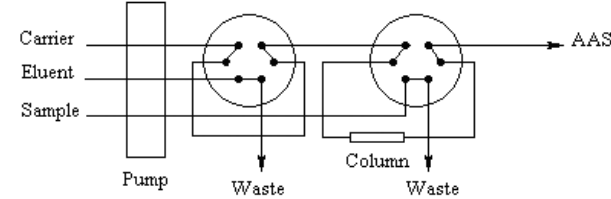

Figure 2. Schematic diagram of the flow system used for preconcentration and determination of zinc: (a) sample loading; (b) eluent injection

\section{RESULTS AND DISCUSSION}

Alumina has positively charged surfaces in acidic solution and so can strongly adsorb the negatively charged Alizarin Red S (ARS) in this media. In preliminary studies, the sorption of $30 \mathrm{mg}$ of ARS from $50 \mathrm{~mL}$ solution with different $\mathrm{pH}$ on $1 \mathrm{~g}$ alumina was investigated. The suspention was shaken for $30 \mathrm{~min}$ and after centrifugation; the ARS in supernatant solution was measured spectrophotometrically. It was observed that ARS sorbed on $\gamma$-alumina particles completely over a wide range of $\mathrm{pH} 1-5$ and then the sorption decreased by further increase in $\mathrm{pH}$. Therefore, $\mathrm{pH}$ 2-2.5 was selected for preparation of sorbent. Furthermore, the effect of shaking time on the sorption of $30 \mathrm{mg}$ ARS from $50 \mathrm{~mL}$ sample solution on $1 \mathrm{~g} \gamma$-alumina was also investigated at $\mathrm{pH} 2.5$. The results showed that sorption of ARS on $\gamma$-alumia increased up to ca. $15 \mathrm{~min}$ and then leveled off. A time of 20 min was selected for preparation of sorbent. In these conditions, when acidified ARS solution was shaken with alumina, the ARS was homogeneously adsorbed on alumina surface, which causes the alumina color to change from white to red.

\section{Chemical and hydrodynamic variable}

In order to establish the best chemical and FI conditions for the retention and elution of the analytes, the experimental procedure was optimized by using the univariable method. Synthetic sample solution containing $50 \mu \mathrm{g} \mathrm{L}^{-1}$ of $\mathrm{Zn}^{2+}$ were employed for these studies.

The $\mathrm{pH}$ value of the solutions has a critical role on the overall performance of the SPE method. It affects the retention of the metals ions on chelating sorbent. The effect of $\mathrm{pH}$ on retention of zinc was studied in the range of 2-9. According to the results shown in Figure 3, the optimum $\mathrm{pH}$ range for retention of zinc on microcolumn is 5.5-8.5. The progressive decrease in the retention of analytes at low $\mathrm{pH}$ is due to the competition of the hydrogen ions with analyte for adsorption on chelating sorbent; while, the

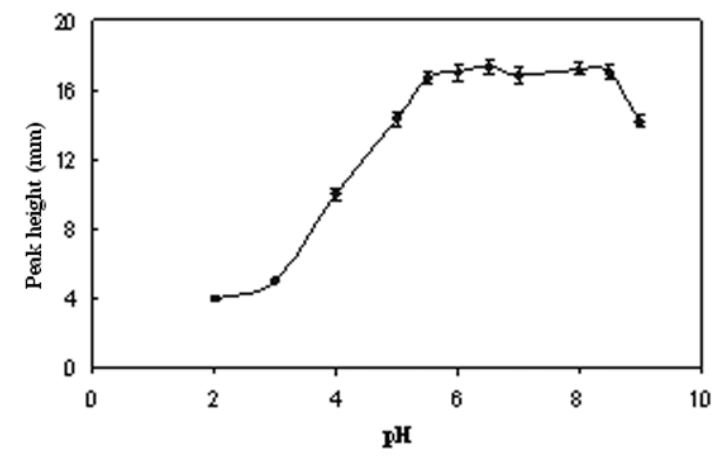

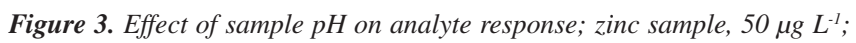
sampling volume $10 \mathrm{~mL}$; eluent nitric acid $\left(250 \mu \mathrm{L}, 1 \mathrm{~mol} \mathrm{L^{-1 }}\right)$ 
decrease in adsorption at higher $\mathrm{pH}$ is probably due to analytes hydrolysis and hydroxide ion interference. Therefore, the $\mathrm{pH}$ of 6.5 was selected for subsequent work.

The length of microcolumn was found to have significant effect on peak height of analyte. The influence of the length of microcolumn was investigated in the range of $1-6 \mathrm{~cm}$. The signal peak height was maximum and constant at a microcolumn length of 2-4 cm. The decrease in the peak height of greater than $4 \mathrm{~cm}$ is due to peak broadening associated with longer column. A $3 \mathrm{~cm}$ microcolumn was used for subsequent study.

The effect of the sample loading rate in the range of 1 to $7 \mathrm{~mL} \mathrm{~min}^{-}$ ${ }^{1}$ on the preconcentration process was checked. Results demonstrated (Figure 4) that for a flow rate less than $5 \mathrm{~mL} \mathrm{~min}^{-1}$ signal response was independent of flow rate. Use of higher flow rate, however, resulted in a sharp decrease in signal, suggesting impaired deposition efficiency as a consequence of short contact time. Subsequent sample loading

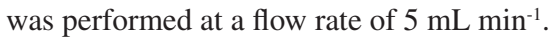

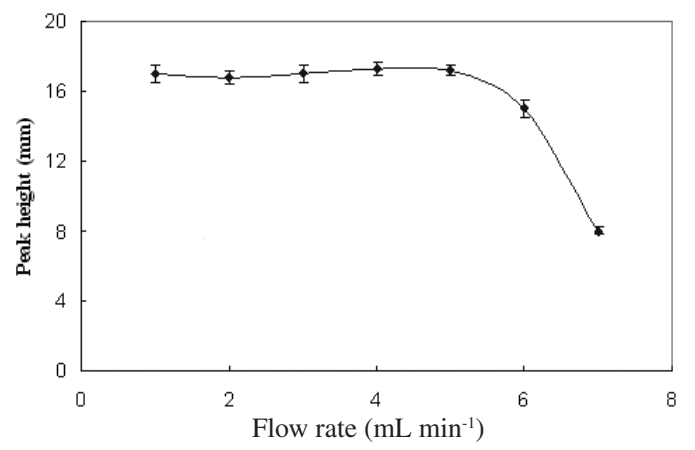

Figure 4. Effect of sample flow rate on analyte response; zinc sample, $50 \mu \mathrm{g}$ $\mathrm{L}^{-1}$; sampling volume $10 \mathrm{~mL}$; eluent nitric acid $\left(250 \mu \mathrm{L}, 1 \mathrm{~mol} \mathrm{~L}{ }^{-1}\right)$

The elution of analyte from the microcolumns was studied by using nitric acid solutions at different concentration $\left(0.25-3 \mathrm{~mol} \mathrm{~L}^{-1}\right)$, as stripping agent. Figure 5 shows that with $250 \mu \mathrm{L}$ eluent, the peak height response was increased with nitric acid concentration up to $0.75 \mathrm{~mol} \mathrm{~L}^{-1}$ and then leveled off, at higher concentration; therefore, for subsequent work, nitric acid with a concentration of $1 \mathrm{~mol} \mathrm{~L}^{-1}$ was chosen as eluent.

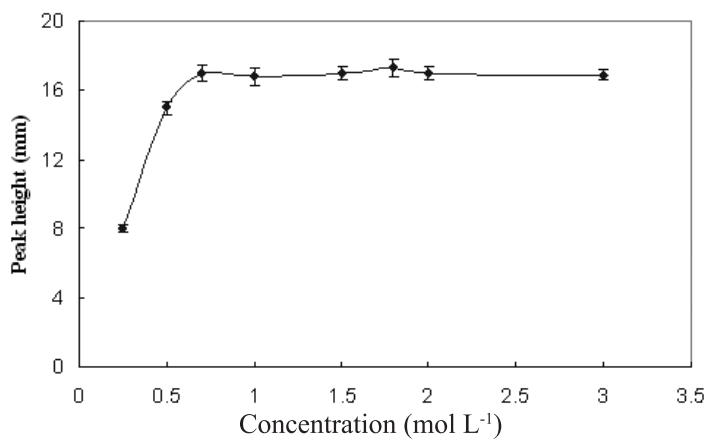

Figure 5. Effect of eluent concentration on elution of analyte from microcolumn; zinc sample, $50 \mu \mathrm{g} \mathrm{L}^{-1}$; sampling volume $10 \mathrm{~mL}$; eluent nitric acid (250 $\mu L$, varied concentration)

The influence of flow rate of eluent $\left(1 \mathrm{~mol} \mathrm{~L}^{-1}\right.$ nitric acid) in analyte desorption from the microcolumn was also studied by varying the flow rate between 1 to $7 \mathrm{~mL} \mathrm{~min}{ }^{-1}$. The results showed that the analytical signal is maximum and constant at flow rate within the range of 3-6 $\mathrm{mL} \mathrm{min}^{-1}$. The decreased in analytical signal at flow rates less than $3 \mathrm{~mL} \mathrm{~min}-1$ is due to incompatibility between elution and nebulization flow rates. Thus, in the subsequent studies a flow rate of $4 \mathrm{~mL} \mathrm{~min}{ }^{-1}$ was selected as the elution flow rate.
The effect of eluent volume was studied using several eluent loops with volumes between 100 and $400 \mu \mathrm{L}$. The smallest volume of eluent sufficient for complete recovery of retained analyte was found to be 200 $\mu \mathrm{L}$ Therefore, a volume of $250 \mu \mathrm{L}$ was chosen for subsequent work.

The absorption capacity of Alizarin Red S modified alumina for $\mathrm{Zn}$ (II) was studied in the batch method. The experiment was performed by adding $1 \mathrm{~g}$ of adsorbent to $100 \mathrm{~mL}$ of solution $(\mathrm{pH}$ 6.5) containing $2 \mathrm{mg}$ of $\mathrm{Zn}(\mathrm{II})$. The mixture was shaken with a mechanical shaker for $10 \mathrm{~min}$ and then filtered through a sintered glass funnel. The amount of zinc left in the filtrate was determined by FAAS. The capacity of the sorbent was found to be $1.26 \mathrm{mg} \mathrm{g}^{-1}$. This high value suggested high performance of the microcolumn for zinc enrichment even in the presence of competing ions. Furthermore, the high capacity of microcolumn permitted large sample volumes to be preconcentrated without degradation in its performance.

\section{Analytical performance}

Under the optimum condition with the use of $25 \mathrm{~mL}$ sample solution, the calibration graph exhibited linearity over the concentration range of $1-100 \mu \mathrm{g} \mathrm{L}^{-1}$ of zinc. Equation of calibration graph was $\mathrm{H}=$ $0.8617 \mathrm{C}+0.7924\left(\mathrm{C}\right.$ being the zinc concentration, $\mu \mathrm{g} \mathrm{L^{-1 } )}$ with a correlation coefficient of 0.9998 .

The relative standard deviation (RSD) for seven replicate measurements of $20 \mu \mathrm{g} \mathrm{L}^{-1}$ zinc with a sample volume of $25 \mathrm{~mL}$ was $3.0 \%$. The limit of detection based on three times the standard deviation of the blank signal with a sample volume of $25 \mathrm{~mL}$ was found to be $0.2 \mu \mathrm{g} \mathrm{L} \mathrm{L}^{-1}$ of zinc. The analytical throughput of $11 \mathrm{~h}^{-1}$ was achieved for $25 \mathrm{~mL}$ sampling volume. A single column was used more than 10 times without a significant change in its response.

The experimental preconcentration factor for a sample volume of $25 \mathrm{~mL}$, based on the ratio of the slopes of the calibration graphs with and without preconcentration, was found to be 144 .

\section{Effect of various ions}

Some experiments were carried out to examine the effects of coexisting ions on the adsorption of zinc on microcolumn. In these experiments, various coexisting ions were added to the solution containing $10 \mu \mathrm{g} \mathrm{L}^{-1}$ of zinc, and the recommended procedure was applied. A relative error of less than 5\% was considered to be within the range of experimental error. The results are shown in Table 1. The ions considered at the mol ratio given in the table, did not show any interference in the measurement of analytes.

\section{Applications}

The method was applied to the determination of zinc in river water, sea water, waste water, human hair, urine and saliva. The reliability of method was checked by recovery experiments and comparing the results with data obtained by electrothermal atomic absorption analysis. The results are shown in table 2 . The proposed method gave satisfactory average recoveries, and there is good agreement between the results and data obtained by furnace atomic absorption analysis.

\section{CONCLUSIONS}

Preconcentration and matrix separation with a microcolumn of Alizarin Red S-modified alumina combined with FAAS has proved to be a reliable method for the determination of zinc. The proposed FI on-line separation and preconcentration showed remarkable advantages as follows: the preparation of sorbent is simple and fast; the 
Table 1. Effect of diverse cations and anions on the recovery of zinc: analyte concentration $10 \mu \mathrm{g} \mathrm{L}^{-1}$; concentrated volume $10 \mathrm{ml}$; $\mathrm{pH} 6.5$; flow rate $5 \mathrm{~mL} \mathrm{~min}^{-1}$

\begin{tabular}{lcc}
\hline Ion & $\begin{array}{c}\text { Mole ratio } \\
\text { Ion/Zn } / \%)\end{array}$ & Recovery* \\
\hline $\mathrm{Na}^{++}$ & 1000 & $95.2 \pm 1.9$ \\
$\mathrm{~K}^{+}$ & 1000 & $96.1 \pm 1.3$ \\
$\mathrm{Mg}^{2+}$ & 1000 & $95.3 \pm 2.4$ \\
$\mathrm{Ca}^{2+}$ & 500 & $100.5 \pm 0.9$ \\
$\mathrm{Fe}^{3+}$ & 200 & $96.0 \pm 1.4$ \\
$\mathrm{Cd}^{2+}$ & 200 & $97.3 \pm 1.6$ \\
$\mathrm{~Pb}^{2+}$ & 200 & $95.2 \pm 2.7$ \\
$\mathrm{Co}^{2+}$ & 200 & $102.1 \pm 1.3$ \\
$\mathrm{Ag}^{+}$ & 200 & $95.9 \pm 1.8$ \\
$\mathrm{Cr}^{3+}$ & 200 & $101.2 \pm 1.7$ \\
$\mathrm{Ni}^{2+}$ & 500 & $97.3 \pm 1.5$ \\
$\mathrm{Mn}^{2+}$ & 500 & $96.1 \pm 1.3$ \\
$\mathrm{Cu}^{2+}$ & 100 & $99.2 \pm 0.9$ \\
$\mathrm{Br}^{2+}$ & 500 & $99.1 \pm 1.5$ \\
$\mathrm{Cl}^{-}$ & 1000 & $95.1 \pm 1.2$ \\
$\mathrm{CO}_{3}^{2-}$ & 1000 & $98.1 \pm 1.4$ \\
$\mathrm{SO}_{4}^{2-}$ & 1000 & $99.9 \pm 1.7$ \\
$\mathrm{PO}_{4}^{3-}$ & 800 & $97.2 \pm 2.1$ \\
\hline
\end{tabular}

*Average and standard deviation of three determinations.

Table 2. Determination of zinc in different samples; concentrated volume $25 \mathrm{~mL}$ for water, waste water and urine samples and $5 \mathrm{~mL}$ for hair and saliva samples; $\mathrm{pH} 6.5$; flow rate $5 \mathrm{~mL} \mathrm{~min}^{-1}$

\begin{tabular}{lcccc}
\hline Sample & $\begin{array}{c}\text { Added } \\
\left(\mu \mathrm{g} \mathrm{L}^{-1}\right)\end{array}$ & $\begin{array}{c}\text { Found }^{\mathrm{a}} \\
\left(\mu \mathrm{g} \mathrm{L}^{-1}\right)\end{array}$ & $\begin{array}{c}\text { Recovery } \\
(\%)\end{array}$ & $\begin{array}{c}\mathrm{GF}^{2} \mathrm{AAS} \\
\left(\mu \mathrm{g} \mathrm{L}^{-1}\right)\end{array}$ \\
\hline Sea water & - & $15.0 \pm 0.4$ & - & $15.2 \pm 0.5$ \\
River water & 20.0 & $35.4 \pm 1.2$ & 102.0 & - \\
& - & $10.1 \pm 0.3$ & - & $10.4 \pm 0.3$ \\
Waste water & - & $75.1 \pm 1.5$ & - & - \\
& 20.0 & $29.8 \pm 0.9$ & 98. & - \\
Human hair & - & $82.1 \pm 1.8$ & - & $81.5 \pm 2.7$ \\
& 10.0 & $91.9 \pm 2.8$ & 98.0 & - \\
Urine & - & $50.1 \pm 1.6$ & - & $50.8 \pm 1.9$ \\
& 20.0 & $70.4 \pm 2.7$ & 101.5 & - \\
Saliva & & $49.3 \pm 1.7$ & - & $48.6 \pm 1.6$ \\
& 20.0 & $69.0 \pm 2.8$ & 98.5 & - \\
\hline
\end{tabular}

${ }^{\mathrm{a}}$ Average and standard deviation of three determinations; ${ }^{\mathrm{b}} \mu \mathrm{g} \mathrm{g}{ }^{-1}$

detection limit $\left(0.2 \mu \mathrm{g} \mathrm{L}^{-1}\right)$ is low enough for trace analysis of zinc and enrichment factor (144 with $25 \mathrm{~mL}$ of sample) is high. These advantages make it a very sensitive procedure for determination of zinc in various matrices in comparison with previously reported on-line preconcentration methods. ${ }^{34-38}$ In addition the method has adequate accuracy and selectivity and it can be used for determination of zinc in different samples.

\section{REFERENCES}

1. Fraige, K.; Crespilho, F. N.; Rezende, M. O. O.; Quim. Nova 2007, 30, 588

2. Koh, J. Y.; Mol. Neurobiol. 2001, 24, 99.

3. Pereira, M. G.; Arruda, M. A. Z.; Microchim. Acta 2003, 141, 115

4. Cordero, M. T. S.; Alonso, E. I. V.; Torres, A. G.; Pavon, J. M. C.; J. Anal. At. Spectrom. 1996, 11, 107.

5. Taher, M. A.; Talanta 2000, 52, 181.

6. Giokas, D. L.; Paleologos, E. K.; Prodromidis, M. I.; Karayannis, M. I.; Talanta 2002, 56, 491.

7. Kendüzler, E.; Türker, A. R.; Anal. Sci. 2002, 18, 917.

8. Cerrato Oliveros, M. C.; Jimenez de Blas, O.; Pérez Pavón, J. L.; Moreno Cardero, B.; J. Anal. At. Spectrom. 1998, 13, 547.

9. Wantanabe, H.; Tanaka, H.; Talanta 1978, 25, 585.

10. Esmadi, F. T.; Khasawneh, I. M.; Kharo, A. F.; Attiyat, A. S.; Can. J. Appl. Spectrosc. 1992, 37, 119.

11. Akl, M. A.; Bull. Korean Chem. Soc. 2006, 2, 725.

12. Fang, Z.; Flow Injection Separation and Preconcentration, John Wiley: Chichester, 1993, p. 25.

13. Ferreira, S. L. C.; Brito, C. F.; Dantas, A. F.; Costa, A. C. S.; Talanta 1999, 48, 1173

14. Dadfarnia, S.; Haji Shabani, A. M.; Gohari, M.; Talanta 2004, 64, 682.

15. Di Nezio, M. S.; Palomeque, M. E.; Band, B. S. F.; Quim. Nova 2005, 28, 145.

16. Pena, Y. P. D.; Gallego, M.; Valcarcel, M.; Talanta 1995, 42, 211.

17. Cerutti, S.; Moyano, S.; Gásquez, J. A.; Stripeikis, J.; Olsina, R. A.; Martinez, L. D.; Spectrochim. Acta Part B 2003, 58, 2015.

18. Khayatian, G.; Pouzesh, S.; J. Iran Chem. Soc. 2007, 4, 490.

19. McLeod, C. W.; J. Anal. At. Spectrom. 1987, 2, 549.

20. Zhang, Y.; Riby, P.; Cox, A. G.; McLeod, C. W.; Date, A. R.; Cheung, Y. Y.; Analyst 1988, 113, 125.

21. Karakaya, A.; Taylor, A.; J. Anal. At. Spectrom. 1989, 4, 261.

22. Yamada, K.; McLeod, C. W.; Kujirai, O.; Okachi, H.; J. Anal. At. Spectrom. 1992, 7, 661.

23. Cox, A. C.; McLeod, C. W.; Miles, D. L.; Cook, I. G.; J. Anal. At. Spectrom. 1987, 2, 553.

24. Dadfarnia, S.; Jafarzadeh, M. H.; Microchem. J. 1999, 63, 226.

25. Brajter, K.; Dabek-Zlotorzynska E.; Talanta 1990, 37, 613.

26. Trojanowics, M.; Pyrzynska, K.; Anal. Chim. Acta 1994, 2, 247.

27. Dadfarnia, S.; Assadollahi, T.; Haji Shabani, A. M.; J. Hazard. Mater. 2007, 148, 446 .

28. Haji Shabani, A. M.; Dadfarnia, S.; Dehghan, K.; Talanta 2003, 59, 719.

29. Nagahiro, T.;Wang, G. F.; Satake, M.; Microchem. J. 1995, 52, 247.

30. Ruedas Rama, M. J.; Ruiz Medina, A.; Molina Diaz, A.; Talanta 2005, 66, 1333.

31. Korn, M. G. A.; Jaeger, H. V.; Silva, N. M. S.; Costa, A. C. S.; J. Braz. Chem. Soc. 2004, 15, 212.

32. Saxena, R.; Singh A. K.; Sambi, S.S.; Anal. Chim. Acta 1994, 295, 199.

33. Dadfarnia, S.; Haji Shabani, A. M.; Jafari, A. A.; Saadat, Z.; Tamaddon, F.; J. Can. Anal. Sci. Spect. 2006, 51, 302.

34. Cassella, R. J.; Bitencourt, D. T.; Branco, A. G.; Ferreira, S. L. C.; Jesus, D. S.; Carvalho, M. S.; Santelli, R. E.; J. Anal. At. Spectrom. 1999, 14, 1749 .

35. Cassella, R. J.; Magalhães, O. I. B.; Couto, M. T.; Lima, E. L. S.; Neves, M. A. F. S.; Coutinho, F. M. B.; Anal. Sci. 2005, 21, 939.

36. Tony, K. A.; Kartikeyan, S.; Vijayalakshmy, B.; Rao, T. P; .Lyer, C. S. P.; Analyst 1999, 124, 191.

37. Liu, Y.; Ingle, J. D.; Anal. Chem. 1989, 61, 525.

38. Lemos, V. A.; Santos, W. N. L.; Santos, J. S.; Carvalho, M. B.; Anal. Chim. Acta 2003, 481, 283. 